\title{
Spatial and environmental components of evolutionary change: interactive effects of salinity and temperature on Fucus vesiculosus as an example
}

\author{
G. Russell \\ Department of Botany, The University; Liverpool L69 3BX, England, U. K.
}

\begin{abstract}
Intertidal algae experience aerial temperatures as well as those of ambient seawater and, during their periods of emergence, are subject to considerable variation in salinity. The eastern Atlantic distribution of Fucus vesiculosus L. (Phaeophyta) lies within the $5^{\circ}$ and $20^{\circ}$ August isotherms. Experiments indicate that this plant can survive temperatures above and below these at normal salinity $(34 \%$ ). However, at extreme temperatures it is evidently much more susceptible to saline changes than at those of the limiting isotherms. Thus the temperature limits for surviving acute saline change appear to give a better biogeographical fit than temperature alone. Nevertheless, the presence of $F$. vesiculosus in estuaries at or near both geographical limits is inconsistent with the experimental results obtained from British plants. Some population divergence may therefore have occurred.
\end{abstract}

\section{INTRODUCTION}

Local patterns of species distribution are not, as a rule, of primary concern to the algal biogeographer; and the numerous, varied factors that influence local populations are seldom discussed prominently in biogeographical literature. Marine biogeography is concerned, above all, with spatial patterns on a global scale, and the chief environmental determinant of species limits is usually held to be mean surface seawater temperature. This map-thermocline approach has successfully demonstrated the existence of major floristic patterns and has, at the same time, generated hypotheses concerning the temperature tolerance of species. In several cases, these hypotheses have been tested experimentally and upheld (see for example Lüning, 1984; Yarish et al., 1984; Cambridge et al., 1984).

A separate, but related, activity is to deduce evolutionary events from biogeographical observations. If this aim is intended, then it becomes necessary to invoke temperature histories of ancient seas and the processes of continental drift. In both its spatial and evolutionary respects, seaweed biogeography has made noteworthy advances in recent years (Hoek, 1982a, b; Lüning, 1985).

However, local aspects of species distribution are of potential interest to the biogeographer, especially in relation to the study of temperature effects. Plants at high bathymetric levels of tidal shores experience terrestrial climatic temperatures as well as those of surface waters. They are also exposed periodically to salinity-desiccation factors that vary in severity. So it is open to question whether the temperature tolerances of such species 
relate more to those of sea than air. It is also pertinent to ask if temperature operates singly as an agent of natural selection, or jointly.

Fucus vesiculosus $\mathrm{L}$. is probably the most common fucoid of $\mathrm{N}$. Atlantic rocky shores. On the eastern seaboard its distribution extends from E. Greenland and N. Russia to Morocco (Powell, 1963). Its northern limit lies a little to the north of the $5^{\circ}$ August isotherm while its southern boundary approximates to the $20^{\circ}$ August isotherm. This species may therefore be identified as a member of the amphiatlantic temperate group (Hoek, 1982b). F. vesiculosus is intertidal and emergent for most of its range, but its ability to live in a permanently submerged state is evident from its presence in rock pools (Lubchenco, 1982) and from its strictly sublittoral distribution in the Baltic Sea (Powell, 1963). The geographical range of this species therefore involves a broad band of seawater temperatures while its intertidal habitats embrace a very considerable variety of emergent temperature conditions. Consequently, it is appropriate material for a comparative examination of the factors that may limit its distribution, locally and geographically.

\section{MATERIALS AND METHODS}

All material was collected from the middle of the eulittoral zone on Hilbre Island, R. Dee, N. W. England. This is an outer estuarine locality with on-shore surface seawater temperatures varying seasonally from $1.5^{\circ}$ to $18.5^{\circ} \mathrm{C}$. Surface water salinities vary similarly from 27-33\% (D. Thomas, pers. comm.). Fucus plants were transported to Liverpool within two hours of collecting and placed in an aquarium containing aerated Irish Sea water (I.S.W.) obtained from Menai Straits, N. Wales (salinity ca $34 \%$ ). All experiments were initiated within $48 \mathrm{~h}$ of collection and were carried out on apical portions of vegetative thallus selected for absence of damaged tissue and visible epiphytes.

The method, explained diagramatically in Figure 1, used photosynthetic oxygen emission (net) as an index of cell damage. Excised tissues were first acclimated to the selected, experimental temperature in I.S. water overnight. The pieces were then transferred individually to flasks containing water of salinity $0,6,11,34,68$ or $102 \%$. The

1

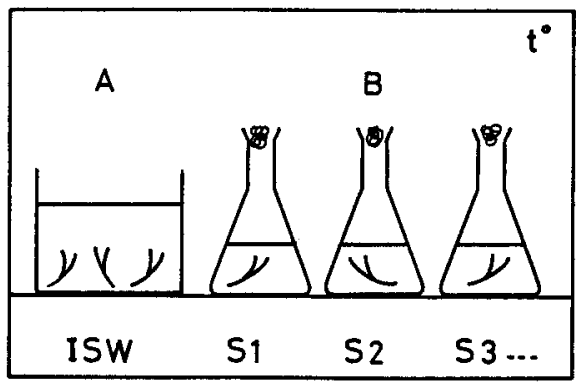

2

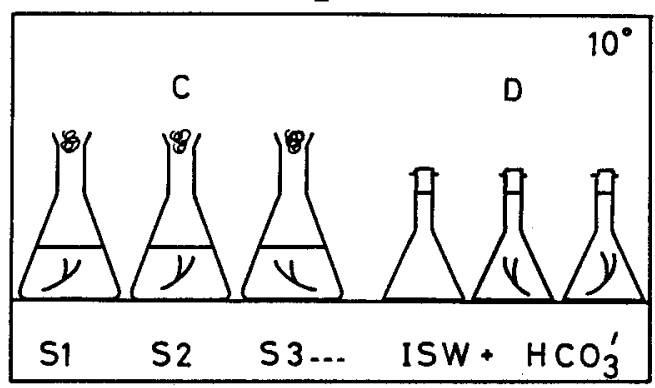

Fig. 1. Diagram showing experimental procedure for measuring temperature-salinity damage to Fucus tissue. Stage 1 involves temperature acclimation (A) in Irish Sea water (I.S.W.) before incubation for $48 \mathrm{~h}(\mathrm{~B})$ in the experimental salinities $\left(S_{1}, S_{2}, S_{3} \ldots\right.$ ). In the second stages (2), the treatment flasks are brought to $10^{\circ} \mathrm{C}$ (C) before transfer to Winkler flasks (D) containing Irish Sea water plus $\mathrm{NaHCO}_{3}$ 
various salinities were obtained by diluting I.S. water with distilled water, or by evaporating over gentle heat $\left(80-90^{\circ} \mathrm{C}\right)$. The flasks were incubated for $48 \mathrm{~h}$ then transferred to a $10^{\circ}$ room until the temperature had once again stabilized (ca $2 \mathrm{~h}$ ). The tissue portions were then removed and placed in glass-stoppered bottles filled with I.S. water, also at $10^{\circ} \mathrm{C}$. This water had been degassed beforehand by boiling and then, when cool, enriched by the addition of $\mathrm{NaHCO}_{3}$ to give a final concentration of $5 \mu \mathrm{mol}$. These flasks were incubated for $2.5 \mathrm{~h}$ under cool white fluorescent light at a photon fluence rate of $94 \mu$ $\mathrm{mol} \mathrm{m} \mathrm{m}^{-2} \mathrm{sec}^{-1}$. The tissues were then removed and oven-dried before weighing, and the amount of dissolved oxygen present in the flasks was determined by standard Winkler technique. All treatments were applied in triplicate and each set of Winkler bottles included a trio of Fucus-free controls. The only departure from this method occurred in the case of the lowest temperature $\left(-18^{\circ} \mathrm{C}\right)$. The material in this experiment was kept overnight at $10^{\circ} \mathrm{C}$ in the various salinities, then removed from the water, placed separately in labelled polythene bags and transferred to the freezing compartment for $48 \mathrm{~h}$. The tissues were thawed at $10^{\circ} \mathrm{C}$ and the experiment completed as described above.

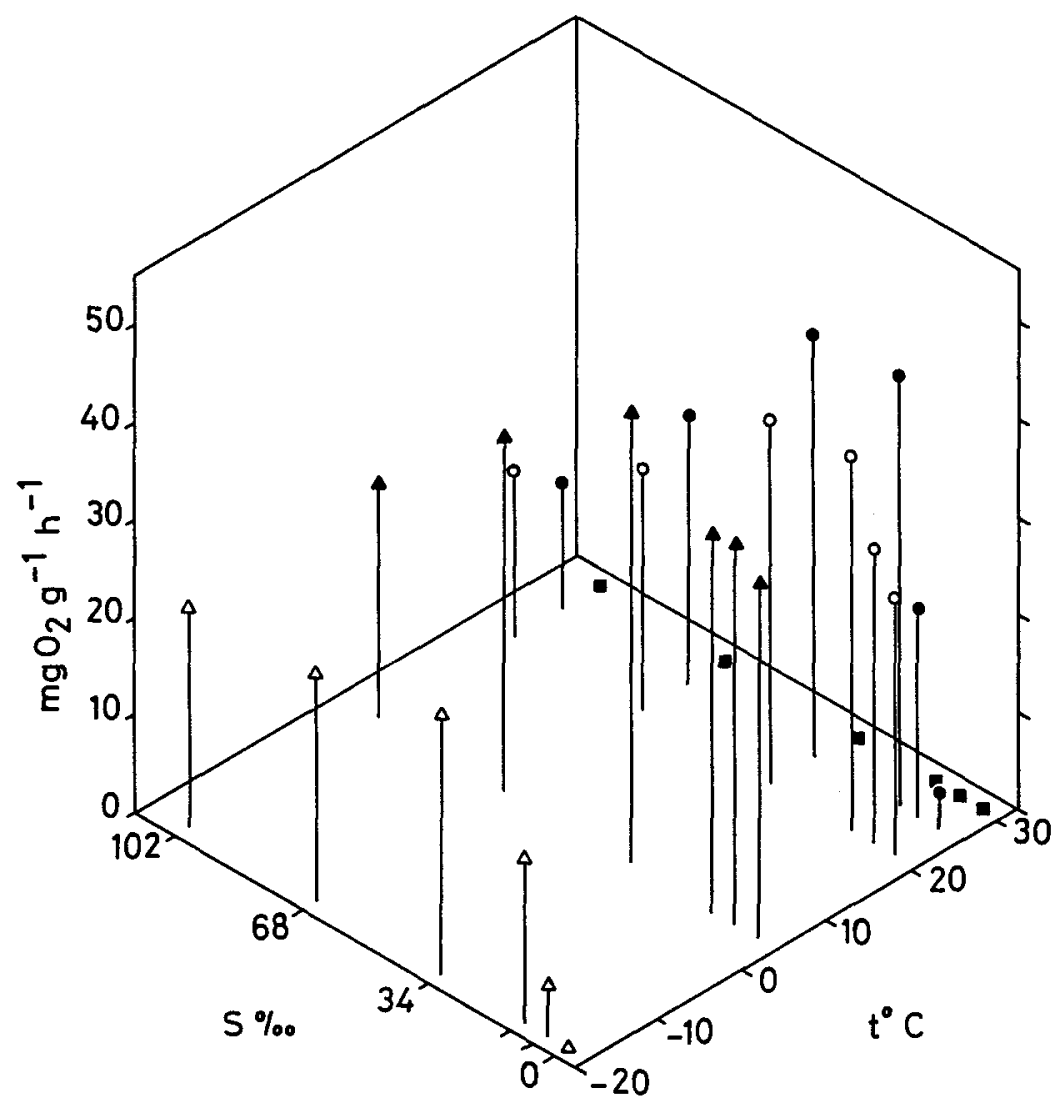

Fig. 2. Net oxygen production in $\mathrm{mg} \mathrm{g}^{-1}$ dry weight $\mathrm{h}^{-1}$ per litre I.S.W. at $10^{\circ} \mathrm{C}$ in temperaturesalinity stressed Fucus vesiculosus. Salinity (\%o) and temperature $\left({ }^{\circ} \mathrm{C}\right)$ values are indicated on the appropriate axes 
It is experimentally more satisfactory to measure oxygen output in recovery conditions, as here, than in the salinity treatment flasks. Algal cells that experience saline shock undergo considerable changes in volume. These changes may affect the permeability of the cell membrane and, particularly in the case of downshock, result in misleadingly high dissolved oxygen values. The fact that oxygen solubility in water varies with temperature and salinity argues also for measurement of oxygen output under constant conditions. Another advantage of this method is that it demands a smaller number of controls and is hence more economical in bench time.

The principal source of error is self-shading at the final stage of the method, if overlarge thallus pieces are used. As far as possible, Winkler flasks should be equally and lightly loaded.

\section{RESULTS}

The results are given in Figure 2, which combines oxygen output, salinity and temperature data in a three-dimensional plot. The results indicate that at temperatures which correspond with the summer isotherms of its geographical limits $\left(4^{\circ} \mathrm{C}, 21^{\circ} \mathrm{C}\right)$, Fucus vesiculosus is productive of oxygen over a wide salinity range. Beyond these temperatures $\left(-18^{\circ} \mathrm{C}, 26^{\circ} \mathrm{C}\right)$ there is evidence of damaged photosynthetic systems. In the case of frozen tissues, pretreatment in $0 \% \mathrm{~S}$ and $6 \% \mathrm{~S}$ was associated with the greatest damage. At $26^{\circ} \mathrm{C}$, however, impaired production was evident at both highest and lowest salinities. The highest temperature of all $\left(31^{\circ} \mathrm{C}\right)$ was lethal, irrespective of salinity, confirming an observation by Schramm (personal communication reported by Gessner, 1970 ) that the upper tolerance limit of submerged $F$. vesiculosus is $30^{\circ} \mathrm{C}$.

\section{DISCUSSION AND CONCLUSIONS}

Interactive effects of salinity and temperature upon marine algae are welldocumented: (see Yarish \& Edwards, 1982, for a discussion of these, and for examples in Caloglossa and Bostrychia species). From the present results it is evident that Fucus vesiculosus emits oxygen over a greater range of temperatures than those associated with the isotherms at its geographical limits. When treated with seawater of salinity $34 \%$, this plant seems most indifferent to temperature, and it is only at the very extremes of the temperatures employed that there is evidence of serious damage to photosynthetic systems. However, the ability to survive for $48 \mathrm{~h}$ temperatures outside those of the limiting isotherms is plainly impaired when salinities also become extreme. At $26^{\circ} \mathrm{C}$, net production is markedly reduced in tissues which had experienced highest and lowest salinities. Freezing was lethal to tissues pretreated with the lowest but not the highest salinities. This observation is consistent with the report in Gessner (1970) that freezing resistance in Porphyra spp. is increased by prior removal of water (cf. also Bird \& McLachlan, 1974, for information on lower temperature limits of Fucus spp.). Perhaps the presence of organic solutes, mobilized in response to high salinities, has also conferred some protection against freezing damage (cf. Steponkus, 1984, for role of solutes in cold hardiness in plants).

Thus the temperature limits for surviving acute saline fluctuations appear to give a better biogeographical fit than those obtained from plant tissues exposed to seawater of normal salinity. If this applies to other intertidal species, then experiments on tempera- 
ture tolerance conducted at optimal salinity, and those on salinity tolerance conducted at optimal temperature, may give results that are difficult to interpret ecologically or biogeographically. Some of these problems may; of course, be artifacts, products of the short-term nature of the experiments. Lüning (1984) has drawn attention to discrepancies between his own observations on the upper temperature limits of certain members of the Delesseriaceae, and those obtained by Biebl (1958). Biebl's experiments were conducted over a $12 \mathrm{~h}$ period while those of Lüning were maintained for 7 days, which may explain the higher tolerances reported by the former, although differences in method may also have been involved. The present author shares the experience of Lüning (1984) in finding considerable microbial development in high-temperature treatments, which could be visible to the naked eye even after as short a time as $24 \mathrm{~h}$. The $48 \mathrm{~h}$ treatment period adopted here lies between those of Biebl and Lüning, and the method of measuring tolerance resembles the latter's. There is always a problem in extrapolating from the results of short-term laboratory experiments to the uncontrolled conditions experienced by plants in nature. Nevertheless, these experiments enable us to identify optimal, suboptimal and lethal conditions which we may compare with those obtaining over the geographical range of a species. In this case, the results are in accordance with the temperature extremes experienced by Fucus vesiculosus at its geographical limits.

However, results may be equally misleading if, as in this case, the experiments are based upon a single plant population. The Hilbre plants used in this exercise would be likely to sustain damage if exposed first to freshwater and then to subzero temperatures. Such conditions might obtain in a stratified estuary when a falling tide leaves plants exposed to freezing air temperatures. It would be tempting to conclude that $F$. vesiculosus at its northern limit must therefore be absent from estuarine habitats. It would also be wrong; for, in Iceland at least, this plant is to be found in inner estuaries (Munda, 1972).

At its southern limit, F. vesiculosus is found only in estuaries (Gayral, 1958). The reasons for its absence from the open coast of Morocco are not known, and could be various, but it would have been difficult to deduce its occurrence in estuaries from the Hilbre results, especially as Moroccan estuaries are liable to be hypersaline as much as hyposaline, and with water temperatures that may exceed $25^{\circ} \mathrm{C}$ (D. Hockin, pers. comm.).

The geographical range of $F$. vesiculosus may thus take the form of population mosaic, and experimental evidence drawn from one population may be inapplicable to others. Given the variability and versatility of this species, there is a strong possibility that ecotype evolution has occurred. So, to conclude, if the phycologist wishes to know about a species at its geographical (or ecological) limits, then the best advice is to go there.

\section{LITERATURE CITED}

Biebl, R., 1958. Temperatur- und osmotische Resistenz von Meeresalgen der bretonischen Küste. Protoplasma 50, 217-242.

Bird, C. J. \& McLachlan, J., 1974. Cold hardiness of zygotes and embryos of Fucus (Phaeophyceae, Fucales). - Phycologia 13, 215-225.

Cambridge, M., Breeman, A. M. \& Hoek, C. van den, 1984. Temperature responses of some North Atlantic Cladophora species (Chlorophyceae) in relation to their geographic distribution. Helgoländer Meeresunters. 38, 349-363. 
Gayral, P., 1958. Algues de la côte atlantique marocaine. Soc. Sci. Nat. Phys. Maroc, Rabat, 523 pp. Gessner, F., 1970. Temperature: Plants. In: Marine ecology. Ed. by O. Kinne. Wiley-Interscience, London, 1 (1), 363-406.

Hoek, C. van den, 1982a. Phytogeographic distribution groups of benthic marine algae in the North Atlantic Ocean. - Helgoländer Meeresunters. 35, 152-214.

Hoek, C. van den, 1982b. The distribution of benthic marine algae in relation to the temperature regulation of their life histories. - Biol. J. Linn. Soc. 18, 81-144.

Lubchenco, J., 1982. Effects of grazers and algal competitors on fucoid colonisation in tide pools. J. Phycol. 18, 544-550.

Lüning, K., 1984. Temperature tolerance and biogeography of seaweeds: The marine algal flora of Helgoland (North Sea) as an example. - Helgoländer Meeresunters. 38, 305-317.

Lüning, K., 1985. Meeresbotanik. Thieme, Stuttgart, $375 \mathrm{pp}$.

Munda, I., 1972. General features of the benthic algal zonation around the Icelandic coast. - Acta nat. islandica 21, 1-36.

Powell, H. T., 1963. Speciation in the genus Fucus L. and related genera. In: Speciation in the sea. Ed. by J. P. Harding \& N. Tebble. System. Ass., London, 63-77.

Steponkus, P. L., 1984. Role of the plasma membrane in freezing, injury, and cold acclimation. - A. Rev. Pl. Physiol. 35, 543-584.

Yarish, C., Breeman, A. M. \& Hoek, C. van den, 1984. Temperature, light and photoperiod responses of some Northeast American and West European endemic rhodophytes in relation to their geographic distribution. - Helgoländer Meeresunters. 38, 273-304.

Yarish, C. \& Edwards, P., 1982. A field and cultural investigation of the horizontal and seasonal distribution of estuarine red algae of New Jersey. - Phycologia 21, 112-124. 